\title{
Outdoor Learning Model in Improving the Quality of Poetry Writing
}

\author{
Cahyaning Oktaviani ${ }^{1}$, St Y Slamet ${ }^{2}$, and Hartono ${ }^{3}$ \\ \{cahyaningoktaviani@student.uns.ac.id'1 , slametsty@yahoo.co.id ${ }^{2}, \&$ hartono@fkip.uns.ac.id ${ }^{3}$ \} \\ ${ }^{1,2,3}$ Universitas Sebelas Maret, Surakarta, Indonesia
}

\begin{abstract}
Writing poetry is something that is not easy for elementary school students to do. The factor that greatly influences the success of learning to write poetry is motivation. This study aimed to describe the outdoor learning model in fostering motivation to write poetry in elementary school students. The fact that there are still many teachers who do not understand how to grow the motivation to write poetry to students is very important. The results of this study indicated that the application of the outdoor learning model could foster motivation to write poetry which has an impact on the increasing quality of poetry writing in elementary school students. Outdoor learning invites students to interact directly with learning objects so that the learning process becomes clearer, real, and enjoyable. Writing motivation can grow in a free and pleasant study room. This study used a qualitative descriptive research method. The subjects of this study were 28 students in grade 4 of elementary school. This study used observation, interviews, and documentation to collect data, and interactive analysis methods to analyze data. An interactive analysis method was used to analyze data.
\end{abstract}

Keywords: outdoor learning, writing, poetry, motivation, learning models

\section{INTRODUCTION}

The $21^{\text {st }}$ century education is expected to produce generation who are able to optimize the potential that exists in them. This era is a challenge for teachers and educators. Teachers must have adequate knowledge and skills to carry out various innovations in learning. Learning that is done is expected to optimize the potential in students. Poetry writing activities are not easy to do because writing good poetry requires special dictions to represent the writer in transferring ideas. Writing poetry requires a high imagination to express ideas [1]. Writing poetry is not easy. It requires creativity to do it.

A student is said to be able to write poetry when writing poetry by choosing the right choice of words and interesting rhymes. However, in fact, there are still many students who have difficulties in writing poetry. Various causes that influence the ability to write poetry in students include lack of motivation in writing poetry, lack of ability to develop ideas, and lack of vocabularies possessed by students [2]. This happens because the teacher has not implemented a learning model that can foster motivation to write poetry in students. Outdoor learning provides a broad opportunity for students to make observations, ask questions, 
analyze, and make conclusions so that students' curiosity can be answered [3]. This broad opportunity can arouse students' motivation in conducting activities, in the discussion of poetry writing activities.

\section{METHOD}

This research is a qualitative descriptive study. Qualitative research methods are methods based on philosophy of postpositivism, while to examine natural objects, where the researcher acts as a key instrument, data collection techniques are carried out by means of triangulation (combined) [4]. Analysis of the data carried out is inductive or qualitative, and the results of the study emphasize meaning rather than generalization. Data collection techniques used interviews, observations, and documents to obtain data about the learning model needed by teachers and students, syllabus, and learning implementation plans used by teachers. Data were collected and then reduced, analyzed, and mitigated so that a description of the research results was obtained. The teacher taught 28 students.

\section{RESULTS AND DISCUSSIONS}

Motivation is individual interest or internal encouragement. Motivation is divided into two, namely extrinsic motivation and intrinsic motivation. Extrinsic motivation is a type of motivation that is influenced by external factors, while intrinsic motivation is an impulse that arises from within the individual. Intrinsic motivation is considered important in encouraging success [5]. Potential in students can be explored optimally if students have high motivation. Motivation plays an important role in the success of learning. Motivation encourages students in carrying out activities. Students who have high motivation will put efforts to be active [6]. The high and low motivation give an impact in an effort to achieve the objectives of an activity. Motivation has a very important role to encourage someone to actively carry out activities. Motivation also serves as a basis for students to get involved or participate in an activity [7]. Someone who has high motivation will try to be actively involved in an activity. Motivation encourages someone to carry out tasks with responsibility [8]. All activities carried out with responsibility will be able to achieve maximum results.

Growing motivation to write poetry can be done by applying the right learning model. The learning model is a whole series of presentation of teaching material which covers all aspects of prior, while, and post learning done by the teacher and all related facilities that are conducted directly or indirectly in the learning process [9]. Learning must be well-planned. Thinking and preparing all aspects needed prior, while, and post learning. The outdoor learning model is a learning model that provides a learning environment that can enhance development and motivate students in learning [10]. Learning outdoors makes students more excited. Outdoor learning facilitates students to interact with the surrounding environment so that they can explore knowledge independently or in groups [11]. Knowledge gained by having self-experiences will be more embedded in students' memories. Learning activities do not have to be done in the classroom. Learning can also be done in the wild, when students are bored inside. Boredom can affect students' learning motivation [12]. The outdoor atmosphere can make students' minds more refreshed.

The advantages of the outdoor learning model, namely activities become more interesting, learning will be more meaningful, more learned materials, learning activities become more active, and learning resources are richer [13]. Outdoor learning has many advantages. The advantages of other outdoor learning can build meaning (input), then processed through cognitive structures so that they impress long in the memory of students [14]. Learning with 
outdoor learning becomes more meaningful. The results of Hastutiningsih's (2016) study also indicated that through outdoor learning various students' potential have the opportunity to develop more optimally because there are real interactions between students and the real world [15]. This encourages students to be able to explore all the potential in themselves optimally.

Steps that must be taken by a teacher in outdoor learning are giving assignments, question and answer, playing, and observing [16]. Assignments given must be related to the materials being studied. Outdoor learning activities with questions and answers are conducted between teachers and students about the materials being studied. Games that are in accordance with the materials can also support the steps in learning activities. Observation activities can be done by observing the outdoors, taking notes, and making conclusions.

Based on the results of observations and interviews with teachers and students, it can be concluded that the use of the outdoor learning model could foster motivation to write poetry that has an impact on the increasing quality of poetry writing in elementary school students. The outdoor learning model invites students to learn in an unusual and pleasant atmosphere. Outdoor situations make the imagination of students able to develop freely. A well-developed imagination can motivate writing poetry. The growth of motivation in writing poetry in students makes learning more meaningful. This is indicated by the increasing quality of students in writing poetry. Improving the quality of writing poetry in students can be seen from the poetic works that have been created. Students are better able to express their thoughts and feelings with strands of beautiful words, use the correct diction, and have broad meanings.

Supported by the results of Agusta's research (2018) using outdoor learning, they indicated an increase in students' creativity and collaboration [17]. Equally, outdoor learning could improve the factors that support the success of achieving learning goals. The results of students interviews after the application of outdoor learning indicated students were happy with the learning situation outside the classroom. Supported by the results of Hojjat's research (2017) that pleasant learning situations can increase students' learning motivation [18]. Different scenes and situations make the mind more refreshed. Pleasant situations and fresh thoughts make students more comfortable in writing poetry. Comfort in learning increases motivation to write poetry. Learning is more meaningful and students are easier to make poetry. This result is supported by a study conducted by Mirrahimmi (2011) which shows that outside learning involving the natural environment increases academic achievement and social emotional intelligence for students [19].

The obstacle experienced by the researchers during implementing the outdoor learning model was that it was time consuming for learning activities. The trip to the learning location also took time. The researchers must compact activities and choose learning locations that are not too far from the school to overcome these obstacles. This is similar to the research of Ernst (2011) which mentions barriers in outdoor learning lack of access to outdoor learning and security issues [20]. Fägerstam's research (2014) also shows challenges with perceived outdoor education, such as the fact that students need time to adjust to new learning environments [21][22].

\section{CONCLUSION}

The outdoor learning model can foster motivation to write poetry in elementary school students. The atmosphere of writing poetry in open spaces is more fun for students. Pleasant learning situations increase students' motivation. Students can be more free to imaginein open spaces. Students can produce original ideas in writing poetry. This learning model supports the success of learning to write poetry which is characterized by the increasing quality of students' 
in writing poetry. Improving the quality of students' poetry writing can be seen from the students' works of poems which contain diction, beautiful words, original ideas, and meaning embedded. The application of the outdoor learning model find obstacles, namely requiring more time in learning, so it is necessary to choose a location that is suitable for learning and not too far away.

\section{REFERENCES}

[1] N. Solihati, "The Effect of Method and Writing Interest on the Students Poetry Writing Ability at Indonesia Language and Literature Education Study Program of Fkip Uhamka," International Journal of Science and Research, vol. 5, no. 10, pp. 1402-1406, 2016.

[2] Y. Wakhyudi and Mulasih, "Pembelajaran Menulis Puisi Pada Siswa Sekolah Dasar Menggunakan Model Pembelajaran Kreatif Berbasis Komunikatif," Jurnal Dialektika Jurusan PGSD, vol. 8, no. 2, pp. 118-133, 2018.

[3] R. S. Nugraha, Sumardi, and G. Hamdu, "Desain Pembelajaran Tematik Berbasis Outdoor Learning di SD," Indonesian Journal of Primary Education, vol. 1, no. 1, pp. 34-40, 2017.

[4] Sugiyono, Metode Penelitian Pendidikan Pendekatan Kuantitatif, Kualitatif, dan R\&D. Bandung: Alfabeta, 2016.

[5] N. M. Valiantien, R. Setyowati, dan S. Ariani, "Igniting Students' Motivation In Writing Through Journal Writing,” Pros. ISELT-4, pp. 155-161, 2016.

[6] M. Yuliandri, "Hubungan Motivasi Belajar dalam Keterampilan Menulis Puisi Pada Proses Pembelajaran," Nusantara (Jurnal Ilmu Pengetahuan Sosial), vol. 1, pp. 31-41, 2016.

[7] A. M. Santoso, M. Amin, S. B. Sumitro, and B. Lukiati, "Learning Motivation of Student During the Implementation of Lecturing Based in Silico Approach," International Journal of Research and Review, vol. 4, no. 9, pp. 6-9, 2017.

[8] S. Suhaimi, M. Akbar, and H. Sjamsir, "The Effect of Pedagogical Competence, Attitude Towards Profession and Motivation on Teachers Performance," in Proceedings of the First International Conference on Technology and Educational Science, 2019, pp. 1-6.

[9] Istarani, 58 Pembelajaran Inovatif (Referensi Guru dalam Menentukan Model Pembelajaran). Medan: Media Persada, 2011.

[10] G. Yildirim and G.O. Akamca, "The Effect of Outdoor Learning Activities on the Development of Preschool Children,"South African Journal of Education, vol. 37, no. 2, pp. 1-10, 2017.

[11] A. A. Nugroho and N. R. Hanik, "Implementasi Outdoor Learning untuk Meningkatkan Hasil Belajar Kognitif Mahasiswa pada Mata Kuliah Sistematika Tumbuhan Tinggi," BIOEDUKASI, vol. 9, no. 1, pp. 41-44, 2016.

[12] A. Rohim, "Pembelajaran di Luar Kelas (Outdoor Learning) dengan Pendekatan PMRI untuk Memahamkan Materi SPLDV," Jurnal Edukasi, vol. 4, no. 1, pp. 18-27, 2018.

[13] Husamah, Pembelajaran Luar Kelas (Outdoor Learning). Jakarta: Prestasi Pustaka, 2013.

[14] Suherdiyanto, P. Mawardi and R. Anggela, "Pembelajaran Luar Kelas (Outdoor Study) dalam Peningkatan Hasil Belajar Siswa di SMA Negeri 1 Sungai Kakap," Sosial Horizon : Jurnal Pendidikan Sosial, vol. 3, no. 1, pp. 139-148, 2016. 
[15] T. Hastutiningsih, A.P.B. Prasetyo and P. Widiyaningrum, "Pengembangan Panduan Pembelajaran Outdoor Bermuatan Karakter Peduli Lingkungan Pada Materi Ekologi," Journal of Innovative Science Education, vol. 5, no. 1, pp. 28-35, 2016.

[16] A. Vera, Metode Mengajar Anak di Luar Kelas (Outdoor Study). Yogyakarta: Divapress, 2012.

[17] A. R. Agusta, P. Setyosari, and C. Sa'dijah, "Implementasi Strategi Outdoor Learning Variasi Outbound untuk Meningkatkan Kreativitas dan Kerjasama Siswa Sekolah Dasar," Jurnal Pendidikan, vol. 3, no. 4, pp. 453-459, 2018.

[18] S. Hojjat, C. Ikemoto, and T. Sowa, "Maze and Mirror Game Design for Increasing Motivation in Studying Science in Elementary School Students," in EAI Endorsed Transactions on Creative Technologies, 2017, vol. 4, no. 12, pp.1-14.

[19] S. Mirrahimi, et al. "Developing Conducive Sustainable Outdoor Learning: The Impact of Natural Environment on Learning, Social and Emotional Intelligence," Procedia Engineering, vol. 20, pp. 389-396, 2011.

[20] J. Ernst, and L. Tornabene, "Preservice Early Childhood Educators' Perceptions of Outdoor Settings as Learning Environments," Environmental Education Research, vol. 18, issue 5, pp. 643-664, 2012.

[21] E. Fägerstam, "High School Teachers' Experience of The Educational Potential of Outdoor Teaching and Learning," Journal of Adventure Education \& Outdoor Learning, vol. 14, no. 1, pp. 56-81 2014.

[22] K. Saddhono and M. Rohmadi, "A Sociolinguistics Study on the Use of the Javanese Language in the Learning Process in Primary Schools in Surakarta, Central Java, Indonesia." Int. Edu. Stu., vol. 7 no.6 pp 25-30, 2014 